ISSN: 0210-7287

DOI: https://doi.org/10.14201/16162020101533

\title{
ALGUNAS NOTAS MÁS EN TORNO A LA CATEGORÍA DE CINE POÉTICO
}

\section{Some More Notes about the Category of Poetic Film}

\author{
José Antonio PÉREz BOwIE \\ Universidad de Salamanca \\ bowie@usal.es
}

Recibido: marzo de 2020; Aceptado: mayo de 2020; Publicado: diciembre de 2020 Ref. Bibl. JOSÉ ANTONIO PÉREZ BOWIE. ALGUNAS NOTAS MÁS EN TORNO A LA CATEGORÍA DE CINE POÉTICO. 1616: Anuario de Literatura Comparada, 10 (2020), 15-33

RESUMEN: Vuelvo de nuevo sobre la categoría de cine poético, sobre la que ya había reflexionado en anteriores trabajos, e intento sistematizar las aproximaciones teóricas en torno a la misma y conectarlas con la actividad de los cineastas que cultivan esa modalidad cinematográfica. Parto de una distinción básica entre poeticidad absoluta (vinculada a la antinarratividad) y poeticidad relativa (que relaciono con una narratividad mitigada) y llevo a cabo un breve recorrido histórico por las manifestaciones principales de ambas y por las teorías surgidas en torno a ellas.

Palabras clave: cine poético; vanguardias cinematográficas; teoría del cine; historia del cine.

ABSTRACT: In this paper I tackle again the category of poetic cinema, about which I had already reflected in previous works, and try to systematize the theoretical approaches around it and connect them with the activity of the filmmakers who cultivate that cinematographic modality. Departing from a basic distinction between absolute poeticity (linked to antinarrativity) and relative 
poeticity (which I relate to a mitigated narrativity), I carry out a brief historical journey through the main manifestations of both and the theories that arose around them. history.

Keywords: poetic cinema; cinematographic avant-garde; film theory; film

\section{PRELIMINAR}

Retomo y amplío en estas páginas algunos trabajos anteriores (Pérez Bowie 2008, 2011 y 2015) en los que abordaba la especificidad del cine lírico e intentaba establecer una tipología de sus diversas manifestaciones. La compleja naturaleza de esa parcela de la cinematografía se evidencia en la multiplicidad de etiquetas utilizadas para designarla (cine poético, lírico, puro, ensayístico, experimental, estructural, vanguardista, antinarrativo, posnarrativo, etc.), las cuales son, a la vez, un reflejo de la falta de precisión de sus límites y de la inevitable y frecuente confusión con otros ámbitos de la actividad cinematográfica, que llega incluso a difuminar las fronteras entre dos campos como el cine de ficción y el cine documental que, aparentemente, estaban bien delimitados. Piénsese, por ejemplo, en la problemática ubicación de un formato claramente híbrido como es el del diario cinematográfico, muy cultivado desde las aportaciones pioneras de Jonas Mekas, en el que confluyen, junto a la reflexión sobre las experiencias vividas, la poesía, el documental y el ensayo.

Partiré de la noción de narratividad, estableciendo la oposición entre cine narrativo y cine no narrativo para ubicar, en principio, dentro de este último la poeticidad cinematográfica. Hay que recordar que las primeras manifestaciones de este género surgen en el ámbito de la vanguardia histórica como reacción al cine comercial mayoritario, el cual, al convertirse, según sus detractores, en un mero dispositivo para contar historias, había renunciado al sugestivo y prometedor horizonte que el manejo de las imágenes en movimiento tenía ante sí como campo de experimentación artística. Pero es necesario admitir que la poeticidad no es del todo incompatible con la narración y es frecuente que filmes concebidos de acuerdo con los patrones narrativos habituales y destinados a un público nada minoritario sean calificados de poéticos. A este respecto puede citarse un comentario de alguien tan poco ortodoxo como Luis Buñuel, quien en 1927, tras asistir a la proyección en París de La dama de las camelias de Fred Niblo, escribía que se trataba de «un cinedrama, sabiamente realizado, conseguido plenamente» y que le resultaba «más nuevo, más insólito que un film de los 
llamados sinfonía visual, capaz de provocar "antes que cualquier otra, una emoción peculiarmente cinematográfica", y donde "el poder sugestivo de la imagen nos arranca violentamente de nuestra butaca». Y concluía afirmando: "Cualquiera dotado de una cierta sensibilidad, podrá, si se lo propone, hacer algo parecido a los ensayos de Madame Dulac, y nadie, excepto los verdaderos artistas del silencio, llegará a construir un film como La dama de las camelias» (Buñuel 1970, 310).

Buñuel se refería, obviamente, al potencial emotivo de las imágenes cinematográficas, las cuales pueden funcionar con total independencia de la historia que narran y actúan directamente sobre los estratos sensoriales del espectador anulando los filtros de la racionalidad y permitiendo el acceso a niveles de la realidad no asequibles por las vías de conocimiento lógicas. A esa capacidad es a la que cabe referirse cuando se habla de cine poético y será la que tendré en cuenta para evitar perdernos en disquisiciones sobre la esencia y características de la poesía. Partiré, entonces, de una distinción básica entre poeticidad absoluta, vinculada a la antinarratividad, y poeticidad relativa, en donde la narratividad está presente, pero de una manera mitigada.

\section{POETICIDAD ABSOLUTA (ANTINARRATIVIDAD)}

El cine manifestó desde sus primeros balbuceos una doble vertiente, oscilante entre su vocación realista de documentar la realidad y sus posibilidades de convertirse en un eficaz instrumento al servicio de la fantasía. El diverso aprovechamiento de las imágenes captadas por el aparato de filmación que llevaron a cabo en sus trabajos pioneros los hermanos Lumière y Georges Méliès mostraba ya esa radical ambivalencia que luego sería subrayada como característica esencial del nuevo medio por algunos de sus primeros teóricos como Rudolf Arheim, quien se refirió a la capacidad simultánea de reproducir con extrema fidelidad la realidad cotidiana y de "realizar» lo irreal -es decir, de presentar la irrealidad con los mismos caracteres de la realidad- y viceversa, de desrealizar lo real sin mengua alguna de su potencia objetiva (Arnheim 1996, 30-31). La expansión comercial del cine relegó la dimensión documental como algo secundario para promover su capacidad como mecanismo productor de ficciones. Ese objetivo se convierte en prioritario cuando el cine alcanza su mayoría de edad y entra en la etapa considerada clásica, convirtiéndose en un vehículo predominantemente narrativo y renunciando tanto a su capacidad de documentar la realidad como a la de experimentar con las posibilidades de su lenguaje para remontarla. Así, optó por privilegiar la artificiosidad 
de la representación diseñando un universo verosímil con leyes propias y capaz de seducir a su numeroso público. Paradójicamente, y al igual que sucede en la literatura y en otros medios artísticos, la ilusión de realidad que transmitía la pantalla no era sino un artificio, resultado de una serie de procedimientos de naturalización.

En el cine clásico, pues, el realismo no venía determinado por el apego del relato cinematográfico a los valores documentales de la imagen sino por el nivel de ilusionismo generado en los procesos de escritura. Como apunta Ángel Quintana, el deseo de verosimilitud de la ficción transformó el relato en un doble del mundo que funcionaba según la coherencia de sus propias leyes diegéticas y que finalizó constituyéndose como una entidad autónoma cuyo peso específico residía en su valor de referencia. No se trataba de un realismo de lo representado que certificaba un mundo preexistente a la imagen, sino de un realismo de la representación en que los componentes del mundo real funcionan como signo, como efectos de realidad (Quintana 2011, 105-106).

Contra esta limitación del cine comercial mayoritario, que renunciaba a sus potencialidades de instrumento de indagación en lo real y de vehículo al servicio de la imaginación creadora para ponerse al servicio de la narración literaria, se levanta la reacción de muchos intelectuales y artistas del periodo de las vanguardias; proponían una alternativa rectificadora de una trayectoria que todos ellos consideraban equivocada y denunciaban la banalidad de los argumentos ofrecidos por la pantalla; el fluir vertiginoso de sus imágenes, que impedía una contemplación demorada, y la imposición de patrones narrativos uniformadores y previsibles. Todo ello había convertido al cine, en el sentir de muchos de esos hombres, en un instrumento de alienación en vez del privilegiado instrumento de revelación que podía haber llegado a ser.

Tales intentos de cine alternativo son la primera manifestación de lo que entendemos como "cine poético" en la medida en que renuncia a las imposiciones miméticas y narrativas del cine comercial para interesarse por los significados plásticos o rítmicos de las imágenes o por la intencionalidad subjetiva de la mirada desde la que se presentaban y de la posible interpretación de la realidad que bajo esa mirada se ofrecía. Se trataba, en definitiva, de privilegiar la faceta desdeñada de la esencial ambivalencia de la imagen cinematográfica, insistiendo en su condición irrealista y evanescente en detrimento de su capacidad analógica, que era la que había garantizado su implantación masiva. Las diversas estrategias mediante las que se evidencia esa actitud resistente (antinarratividad, reflexividad, renuncia a los patrones miméticos habituales) remiten claramente a la poesía por lo que esta implica de subversión o trasgresión de los modelos de 
comunicación habituales, de experimento permanente con el lenguaje y de intento de indagar más allá de la superficie de lo visible.

Esas propuestas pioneras, tanto teóricas como prácticas, incluían diversas estrategias destinadas a hacer del nuevo medio un arte independiente y alejarlo de unas prácticas ilusionistas, referenciales y figurativas caducas (Peña Ardid 1997, 15). Entre ellas destacan la supeditación de la bistoria al discurso, el relieve de los elementos rítmicos y de la dispositio como alternativa a los códigos narrativos clásicos, o la apelación a lo irracional y subjetivo con el propósito de hacer visible la realidad interior y el universo de los sueños.

Puede, así, defenderse la dimensión poética de filmes plenamente autorreferenciales por su condición de abstractos como los de Viktor Eggelin (Rythmus 21, Rythmus 22 y Rythmus 23) o de Hans Richter (Opus 21, Opus 22), basados en el ritmo producido por la repetición de figuras geométricas. O Ballet mécanique, de Fernand Léger y Dudley Murphy, y Entr'acte, de René Clair, en los que se utilizan imágenes reconocibles pero descontextualizadas y conectadas mediante esquemas rítmicos visuales. Otros, como Un chien andalou y L'age d'or (Buñuel), La coquille et le clergyman (Artaud), L'étoile de mer (Man Ray) o La sang d'un poete (Cocteau), mantienen una relación evidente con la estética surrealista al estar constituidos por una sucesión sorpresiva de imágenes que pierden toda relación con el mundo del que proceden para entrar a formar parte de otra realidad que pretende ser expresión de las obsesiones que pueblan el subconsciente del autor ${ }^{1}$.

Esas prácticas se desarrollan en paralelo a un considerable número de textos teóricos que las promueven y analizan, alineándose en su rechazo a los mecanismos mimético-narrativos del cine mayoritario. Así, en las reflexiones que los teóricos del formalismo ruso dedicaron al cine aparecen numerosas referencias a la importancia de los elementos formales en el nuevo arte, especialmente perceptible en aquellas que se apartaban de

1. Resulta útil a este respecto la clasificación de Bordwell y Thompson de los filmes no narrativos entre "abstractos" y "asociativos". Los primeros se construyen en torno a una sucesión de variaciones sobre un tema central y las figuras representadas no han de ser exclusivamente abstractas, pues puede tratarse de objetos reconocibles pero desconectados de su contexto. Los filmes "asociativos", por su parte, sugieren cualidades expresivas y conceptos mediante la mera yuxtaposición de imágenes sin ningún nexo aparente; no se trata, como en la categoría anterior, de subrayar las similitudes visuales, sino de incitar al espectador a buscar una conexión en un proceso comparable al de las técnicas metafóricas de la poesía (BORDwell y THOMPSOn 1995, 119-129). 
los previsibles patrones narrativos del cine comercial ${ }^{2}$. Viktor Shklovski es el primero en oponer cine de prosa y cine de poesía, caracterizando a este último por el predominio de los rasgos formales sobre los semánticos $(1998,138)$. Tynianov, por su parte, opone cine "poético" a cine "narrativo", aclarando que en el primero existe un evidente predominio del «argumento" sobre la "trama", es decir de la "disposición" de los materiales de la historia sobre los contenidos que esta transmite; el ejemplo que aduce de los primitivos filmes cómicos norteamericanos es elocuente en la medida en que en ellos la trama constituía un simple pretexto para el desarrollo de una composición basada en elementos rítmicos visuales (Tynianov 1998, 100). Se podrían citar también las aportaciones en la misma línea de Eikhenbaum cuando habla de la antinarratividad del gran primer plano en su capacidad de abstraer la imagen del decurso temporal cumpliendo una función semejante a la desempeñada por la fermata (pausa silenciosa) en el lenguaje musical (Eikhenbaum 1998a, 77). Esa visibilidad del estilo es, cuando se produce, la que permite a los formalistas calificar al cine como arte, porque, como señala en otro momento, «el argumento en el cine está constituido no sólo por, o ni siquiera tanto, por la progresión de la trama como por los elementos estilísticos» (Eikhenbaum 1998b, 200).

Por su parte, Jean Epstein, quien junto a su trabajo como cineasta desarrolla en los años 20 y 30 una considerable actividad como teórico, se refiere a la capacidad del cine para enriquecer y hacer vibrar la memoria y la imaginación visuales de los espectadores directamente, sin tener que pasar por las operaciones de cristalización y disolución del intermediario verbal». Añade que, por sus características instintivas, sentimentales y emotivas, el pensamiento visual «es apropiado en grado sumo para la función poética» y el cine, «más que ningún otro modo de expresión, se manifiesta constitucionalmente organizado para servir de vehículo a la poesía", especialmente si se tienen en cuenta las condiciones de recepción en las que el espectador, en la oscuridad de la sala, permanece ajeno a cualquier "conmoción de la sensibilidad fuera de la que procede de la película", y se sitúa "en estado de ruptura con las contingencias exteriores [...], suspensión que es condición de todo ensueño" (Epstein 2003, 52).

Entre los teóricos españoles podemos citar a Guillermo de Torre, quien, en un temprano artículo de 1921 publicado en la revista Cosmópolis, proclamaba la incompatibilidad del nuevo arte con todo exceso sentimental

2. Los formalistas trasladan la noción de «extrañamiento» de la literatura al cine, lo que supone una negación de la condición analógica que se atribuía a las imágenes de este, ya que no cabe hablar de fidelidad de tales imágenes a la realidad profílmica sino de una transfiguración estilística de las mismas. Véase al respecto PEÑA ARDID (1992, 63-64). 
para añadir a continuación: «iTodo ha de ser impulso vital, ritmo dionisíaco y energetismo jubiloso en el plano moderno del film!» (Torre 1986, 158). En otro texto publicado algunos años después en Revista de Occidente reclama la separación absoluta del cine respecto a la literatura; o, al menos, de aquellos dos géneros, la novela y el teatro, de los que se venía nutriendo, ya que el futuro del nuevo arte está en tomar la antorcha de la poesía lírica y sustituirla, pues su lenguaje lo capacita para convertirse en un puro juego de imágenes, en «un desfile de visiones susceptibles en su entrecruzamiento, de producir chispazos de metáforas ${ }^{3}$. Y, apoyándose en las opiniones de Epstein, Fernand Léger, Moussinac y otros cineastas de la vanguardia francesa, afirma que el cine, para convertirse en un arte auténticamente creador, ha de renunciar a sus posibilidades miméticas, «eliminando el tema, el sujeto, en todo lo posible, o presentándose reducido a sus puros equivalentes visuales de imagen, volumen y movimiento" (Torre 1926, 120).

En definitiva, puede hablarse, como apunta Oliva Mompeán, de la búsqueda de un cinema "puro" que rechaza la estructura argumental del filme, vista como artificiosa e innecesaria, a la que oponen un cine purificado compuesto de imágenes articuladas sobre el eje fundamental de un ritmo. La vanguardia aportó en ese sentido una fundamental preocupación por la propiedad técnico-estética de los recursos cinematográficos, una pasión por el movimiento, por la expresividad misma de la sensación física, del acontecimiento cinético en sí. Se trataba de dotar de emoción a un conjunto de imágenes sucesivas, expresivas en sí mismas, sin necesidad de ponerlas al servicio de un planteamiento textual (Oliva Mompeán 1991, 134-135).

La herencia de esta línea experimentalista y contestataria es recogida y continuada por los artistas de la vanguardia norteamericana de los años 50 y 60 con autores como Norman MacLaren, los hermanos Whitney, Stan Brakhage, Maya Deren, Sidney Peterson, Kenneth Anger, Jonas Mekas, Gregory Markpoulos, Curtis Harrington o Michel Snow entre otros, en quienes se manifiestan las preferencias, motivos y objetivos de la vanguardia histórica, tanto en la línea de la abstracción como en la recurrencia a la imaginería surrealista ${ }^{4}$. Josep M. ${ }^{a}$ Català apunta que la principal diferencia

3. El razonamiento de Guillermo de Torre no deja de encerrar cierta contradicción en la medida en que desea desvincular el cine de la literatura, pero al final quiere equipararlo con la poesía, aduciendo que muchos de sus procedimientos (la metáfora, entre ellos) pertenecen al ámbito literario.

4. Algunos de los textos programáticos básicos de este movimiento como «Declaración del New American Cinema Group» (1960) o "New American Cinema» de Jonas Mekas (1962) pueden encontrarse en ROMAguera y Alsina 1989, 285-292. Para una exhaustiva información sobre la vanguardia norteamericana consúltese SITNEY 1979. 
entre este movimiento y las vanguardias europeas de los años 20 radica en el salto epistemológico que supone desplazar la cámara desde su tradicional posición objetiva a otra radicalmente subjetiva, generando una mirada fragmentada y relativista; se postula, así, la presencia de un cineasta detrás de la cámara que es el protagonista en primera persona del filme y las imágenes de este son las imágenes de lo que ese sujeto ve, filmadas de tal modo que resulta imposible olvidarnos de su presencia (Català 2005, 123124). Francesco Casetti, por su parte, subraya que todos estos ataques contra la dimensión narrativa, industrial y representativa del cine tienen como objetivo hacer que surja la energía subyacente a todo acto de lenguaje, el dinamismo que hay en cada texto, para lo cual centran toda su atención en los elementos significantes marginando por completo el nivel del significado (Casetti 1994, 244-245).

El desarrollo de estas tendencias que tienen en común la búsqueda de vías alternativas al cine mimético-narrativo mayoritario ha continuado hasta nuestros días experimentando un notable desarrollo con el auge de la tecnología digital y las facilidades que proporcionan la portabilidad de los aparatos y la ausencia de límites para el tiempo de filmación. Mientras que el cine comercial ha puesto esta tecnología al servicio de la espectacularidad, quienes se sitúan al margen de la industria optan por un cine minimalista que redimensiona el valor del tiempo y la capacidad de la imagen para captar lo aleatorio; un cine de observación (como el de Chantal Akerman, Wang Bing, Albert Serra, Lisandro Alonso, James Benning, Pedro Costa o Abbas Kiarostami entre otros), centrado en los detalles, que responde al deseo de llegar a sentir la cadencia del paso del tiempo en el interior de las imágenes. La vocación experimental de todas estas prácticas y su objetivo de profundizar en el acercamiento a la realidad permiten que se las pueda seguir adscribiendo a los territorios de lo poético; y aunque las diferencias entre sus propuestas presentan diferencias notables, todas ellas resultan susceptibles de ser acogidas bajo una etiqueta común como es la de "cine posnarrativo", actualmente en boga, y que resume de modo muy convincente las características que permiten esa adscripción. Horacio Muñoz, en un reciente y esclarecedor libro que ha dedicado a esta modalidad cinematográfica, se refiere en primer lugar al abandono del requisito fundamental perseguido habitualmente por los cineastas, el de contar una historia, para interesarse solo en observar acciones, comportamientos y movimientos, y que el espectador invente su película en la cabeza gracias a la incertidumbre que le genera la falta de trama y de información. Es un cine - añade- de intensidades y sensaciones, emocional antes que intelectual y sensorial antes que narrativo, que se enfrenta a «la cuestión imposible de cómo contar una historia después de haber leído todas las historias" para 
centrarse en el "reconocimiento de los materiales con que se puede contar una historia». Señala, por otra parte, cómo este cine es consciente de los cambios experimentados por el modelo de exhibición y consumo, por lo que se sitúa más allá de las salas, entre la pantalla pequeña del ordenador o del televisor y la sala del museo. Y refleja, en algunos casos, una pérdida de la esencia cinematográfica como consecuencia de la disolución del cine por contacto con otros medios (Muñoz 2017, 11-12).

Antes de concluir el presente apartado es obligado mencionar una de las aportaciones teóricas más importantes a esta dimensión del séptimo arte, que resulta imprescindible para entender la deriva antinarrativa iniciada en las vanguardias y que continúa plenamente vigente en nuestros días. Me refiero a las categorías de "imagen-movimiento" e "imagen-tiempo" acuñadas por Gilles Deleuze, las cuales nos serán también de utilidad a la hora de tratar la noción de poeticidad relativa, a la que enseguida habremos de referirnos.

Deleuze relaciona la imagen-movimiento con el cine convencional y la identifica con el mundo diegético organizado de la narración clásica hollywoodense, el cual se sustenta sobre la coherencia temporal y sobre un montaje racional causa-efecto. En cambio, la imagen-tiempo se basa en la discontinuidad, en la des-vinculación como factor articulador. Mientras aquella va asociada a la exposición diáfana de una situación que establece un conflicto fundamental que deberá resolverse mediante la progresión narrativa y cuyos protagonistas se mueven con un propósito determinado, la imagen-tiempo se desentiende de la lógica lineal para interesarse por los procesos mentales de la memoria, el sueño y lo imaginario; se caracteriza por engendrar planos autónomos cuya causalidad es incierta o inexistente, en un proceso no totalizado donde se rompen los vínculos de la continuidad y la organización panorámica del espacio deja paso a una pantalla entendida como palimpsesto de la memoria. Esta imagen es completamente independiente de cualquier subordinación narrativa; mientras que en la imagen-movimiento los personajes se adaptan al ambiente, a la historia y a las acciones, en la imagen-tiempo los protagonistas son ya de por sí «tiempo", es decir, se pierden en el ambiente y marcan su presencia respecto del mismo. Una diferencia fundamental entre ambas radica en el montaje: mientras que en aquella suele pasar desapercibido, en la imagen-tiempo se pone en evidencia para que los espectadores sean conscientes de él 5 .

5. Resumo muy brevemente lo esencial de ambas categorías expuestas por el autor en los libros dedicados a cada una de ellas (Deleuze 1984 y Deleuze 1987). 
Resulta evidente que en la gran mayoría de los ejemplos de cine antinarrativo mencionados nos encontramos ante una consideración de la imagen como un elemento "sustantivo", de una autonomía plena, que responde a la categoría de imagen-tiempo descrita por Deleuze. Ello implica toda una revolución en la función de la mirada, que ya había sido emprendida por otras artes y a la que un sector del cine contemporáneo se apuntará decididamente. Como explica Jacques Rancière, quien habla de un "arte de la edad estética", esa revolución ha consistido en deshacer "los encadenamientos del arte figurativo, ya sea contrariando la lógica de las acciones encadenadas mediante el devenir-pasivo de la escritura, o bien re-figurando los poemas y cuadros del pasadom. Por consiguiente -añade-, todo el arte del pasado «está ahora disponible para su relectura, revisión, repintado o reescritura ${ }^{6}$; pero también cualquier cosa de este mundo, hasta el objeto más banal, "está a disposición del arte en su doble potencial, como jeroglífico que cifra una época del mundo, una sociedad, una historia $\mathrm{y}$, a la inversa, como presencia pura, como realidad desnuda aderezada con el esplendor nuevo de lo insignificante» (Rancière 2005, 18).

\section{Poeticidad RELATIVA (NARRATIVIDAD Mitigada)}

Hasta aquí he considerado solamente ejemplos de lo que se denominaría poeticidad absoluta, es decir, a aquellas manifestaciones cinematográficas que se rebelan contra los modelos del cine narrativo dominante y se constituyen como alternativas que experimentan nuevas vías de expresión buscando la esencia de lo cinematográfico en una aproximación al lenguaje de la poesía en lugar de suscribir los presupuestos naturalistas y narrativos de otros géneros literarios de mayor popularidad como la novela y el teatro.

Pero la poeticidad no es incompatible con el cine narrativo, aunque su presencia resulte menos perceptible $y$, a menudo, difícil de concretar en unas características perfectamente definidas. El concepto de poesía no se opone, pues, al de narración, sino que nos obliga a admitir una forma de narración distinta, desligada de todo nexo causal y basada en la asociación

6. Una manifestación de ese nuevo camino emprendido por el cine (y que Rancière analiza en su libro) lo constituye Histoire(s) du cinema (1988-1998), filme en donde JeanLuc Godard retoma fragmentos de antiguas películas para comentar sus imágenes contemplándolas en su propia autosuficiencia, desligadas del contexto lógico-narrativo al que estaban adscritas. 
de las imágenes, más ligada a la percepción individual que al desarrollo lógico de los hechos en los que está involucrado el personaje en la historia. De hecho, Jean Epstein, en el texto citado anteriormente, abogaba por el cine como el vehículo idóneo para acercar la poesía al hombre de la calle, como «el instrumento capaz de hacerlo acceder al estado de sublimación por resonancia con el estado poético expresado por el creador", al que las personas cultivadas llegan mediante la literatura, el teatro, la pintura, la música o la escultura; se refiere, así, al cine como

un relajante y sublimador [instrumento] de eficacia apropiada, un productor y transmisor de poesía intensa y fácil en cantidad industrial [...] capaz de hacer participar intensamente a un público numeroso, casi mundial, en conmovedoras ficciones en las que le era lícito consumir el exceso y los restos de una afectividad prohibida.

$Y$ añade:

El film se manifiesta particularmente apto para enriquecer y hacer vibrar la memoria y la imaginación visuales de los espectadores directamente, sin tener que pasar por las operaciones de cristalización y disolución del intermediario verbal [...]. Por ser profundamente instintivo, sentimental y emotivo, el pensamiento visual es apropiado en grado sumo para la función poética [...] y [el cine], más que ningún otro modo de expresión, se manifiesta constitucionalmente organizado para servir de vehículo a la poesía (Epstein 2003, 52-53).

Algunos años más tarde Étienne Fuzellier insistía en esa capacidad del cine; tras reflexionar sobre si la poesía puede ser "rentable» en la pantalla (por tratarse de una modalidad literaria elitista), opinaba que tal vez «la expresión cinematográfica, más familiar y más directa, tenga mayores oportunidades de hacer llegar la poesía allí donde la expresión literaria no puede». Y comentaba que un filme como Les visiteurs du soir (Marcel Carné, 1942) puede haber revelado «a espectadores que ignoraban quizá hasta el nombre de la poesía emociones nuevas, extrañas, que han dejado en ellos la inquietud y la nostalgia de un universo entrevisto" (Fuzellier 1964, 91). Páginas atrás había mostrado su convencimiento de que en el cine «el poeta puede hacer con las imágenes todo lo que hacía antes del cine con las palabras” y jugará con aquellas, al igual que hacía con las palabras, "Sobre el doble teclado del valor intelectual e inteligible de las imágenes y de su valor puramente sensible», añadiendo que "el ritmo tendrá la misma importancia en el poema cinematográfico que en el poema verbal» (Fuzellier 1964, 47-48).

En ese mismo texto Fuzellier apunta a las dos manifestaciones de la poeticidad cinematográfica a la que vengo aludiendo y distingue entre los 
"filmes de pura poesía» (entre los que ubica los filmes "absolutos" de la etapa del cine mudo, que describe como «filmes cortos, raros, poco accesibles, concebidos sin pretensiones comerciales") y aquellos otros que utilizan el formato comercial para insuflarle «un estilo de visión original, una personalidad singular, un temperamento poéticom. En estos últimos -comentala poesía será "más difusa, se refugiará sobre todo en el detalle» y estará más presente «en la medida en que el tema general del filme se aleje de la realidad banal, de lo anecdótico o de la narración lógica». A este respecto opina que, probablemente, exista una relación directa entre la ausencia de elementos narrativos y "la intensidad y la autenticidad poéticas", y que por ello "se imponga con más fuerza el valor a menudo desatendido de las imágenes ofrecidas por la realidad y que el poeta recompone siguiendo un orden que no obedece a la razón y a la causalidad» (Fuzellier 1964, 91-92)7.

La dificultad estriba, no obstante, en dilucidar en qué consiste exactamente esa "autenticidad poética» y en establecer cuál es el grado de «intensidad que permite la adjudicación de la condición de lírico a un filme narrativo. Y prueba de ello es el considerable número de reflexiones teóricas en torno a esta cuestión y el carácter a menudo divergente de las mismas, en las que suelen enfrentarse las posiciones esencialistas con las estrictamente formalistas. Entre las primeras estarían las de quienes argumentan que la poesía se encuentra en la realidad y que es la sensibilidad del cineasta para transferirla a la pantalla lo que confiere a un filme la categoría de lírico, como es el caso de Eric Rohmer (1970) o de Andrei Tarkovski (2005). Frente a ellos se sitúan quienes, partiendo de las teorías formalistas explicativas de las peculiaridades del lenguaje poético, defienden que la poeticidad cinematográfica es el resultado de la aplicación de unos determinados procedimientos técnicos; recuérdense a propósito las reflexiones de Pasolini (1970) sobre la utilización del plano secuencia o los diversos análisis que se basan en evidenciar la aplicación en el cine de recursos característicos de la poesía tales como el uso creativo del lenguaje, la desautomatización, la densidad semántica, la condensación, el empleo de un lenguaje «sobresignificativo», la utilización sistemática de diversos tipos de recurrencia, el predominio de la connotación sobre la denotación o el uso

7. A estas dos categorías de cine poético, Fuzellier añade una tercera, el cine "de dibujos animados", que para él "representa la aportación original de la pantalla a la poesía», una opinión suscrita por otros muchos teóricos y artistas desde la época de las vanguardias. En tal género, comenta, incluso el realizador más verista se atreve «a propuestas más audaces que contienen imágenes y efectos puramente poéticos que recuerdan por su composición rítmica y lineal ciertos filmes mudos de los alrededores de 1925". Y cita como ejemplo la secuencia de la borrachera en el filme Dumbo (1941), de Walt Disney (Fuzellier 1965, 92). 
del símbolo y de la metáfora ${ }^{8}$. Podrían añadirse otros intentos explicativos como los que, desde una perspectiva fenomenológica, ponen el acento en la reacción experimentada por el espectador ${ }^{9}$ o en el grado de conocimiento adquirido por el mismo a través de la capacidad reveladora de las imágenes que le brinda la pantalla ${ }^{10}$. Y todavía cabe hablar, como hace Antoine Vallet, de diferentes tipos de poesía cinematográfica en función de los contenidos del filme. Distingue entre "poesía de lo real» y "poesía de lo imaginario" y, con relación a la primera, afirma, citando a Henri Agel, que el cine puede darnos una visión nueva de la realidad haciendo que nos maravillemos ante aspectos elementales de ella y logrando que signifique algo distinto de lo que percibimos en una primera mirada; en tal sentido, opina que el cine parece ser por su propia naturaleza «la expresión más acabada de una magia poética o, más exactamente, poetizante». La poesía de lo imaginario, por su parte, se da en aquellos casos en que el cine mezcla la realidad y lo sobrenatural plasmando las alucinaciones y ensueños

8. Puede consultarse al respecto el trabajo de Rosario NeIra PiñeIro (2007). Se detiene especialmente en el símbolo como uno de los procedimientos más específicos de la poeticidad que utiliza el cine y recurre a la dicotomía de Jakobson entre analogía y contigüidad, asociadas respectivamente a los polos metafórico y metonímico del lenguaje, y afirma que el símbolo puede basarse tanto en relaciones metafóricas (de analogía) como metonímicas (de contigüidad). Establece, así, que "podemos hablar de símbolo en los casos en que un elemento cualquiera, verbal o visual, adquiere uno o más significados figurados que se superponen a su significado literal» $(2007,296)$.

9. Léanse al respecto las siguientes afirmaciones del cineasta Víctor Erice: «Quizá sea oportuno hablar antes de experiencia poética que de poesía, es decir, de ese trance en el cual, tanto el lector de un poema como el espectador de una película, se sienten conmovidos por un sentimiento difícil de definir, pero que identifican como algo común. En ese trance y por lo que al cine - cierta clase de cine- se refiere, la poesía surge de la pantalla de una forma no buscada de antemano, imprevista, suspendiendo la representación o la progresión de la historia, para dar lugar a uno de esos momentos en que el lenguaje es simultáneamente flecha y herida. Flecha capaz de romper el velo -la ilusión- de la realidad; herida que nos toca el corazón porque acierta a mostrar lo que no se percibe a primera vista, pero que alguna vez, como en un sueño perdido -el de nuestra vida anterior- hemos percibido» (ERICE 1997, 3).

10. Javier Herrera se refiere a Mizoguchi y a Bergman como los dos grandes realizadores que han hecho del cine un medio de conocimiento del mundo, de la vida y de la realidad: "Sus poéticas respectivas suponen la superación de la experiencia perceptiva de la imagen por otra de orden superior, de índole visionaria, que vendría dada por la penetración en los más recónditos recovecos de la intimidad del ser humano con el mínimo posible de intervención del director, lo que llamaba Tarkovski "calma olímpica» y que implicaba tener el autodominio suficiente para prescindir de todo lo que pudiera significar la expresión subjetiva de las propias emociones y sentimientos» (HERRERA 2006, 16-17). 
JOSÉ ANTONIO PÉREZ BOWIE

ubicados en una atmósfera irreal. Para Vallet, el filme maravilloso nunca es totalmente irreal; hay siempre en él una mezcla de dos mundos, el real y el sobrenatural, que debe parecer plausible, al menos según la lógica del sueño (Vallet 1963, 131-132).

Pienso que no es necesario acumular más citas sobre las diferentes especulaciones en torno a poeticidad cinematográfica, cuya presencia en muchas manifestaciones del cine narrativo resulta innegable ${ }^{11}$. Ya hemos visto cómo los formalistas rusos, cuando hablaban de tal categoría, no se referían solo a los experimentos abstractos coetáneos, sino que incluían también aquellos filmes narrativos caracterizados, en palabras de Tynianov, por un evidente predominio del "argumento" sobre la "trama", la cual podía constituir a veces un simple pretexto para el desarrollo de una composición basada en elementos rítmicos visuales. Esa visibilidad de la forma adquiere una relevancia especial en el llamado "cine de autor" de los años sesenta, cuando se reivindica la figura del director como artista, como sujeto de una "escritura" personal, de un "estilo" propio. El lirismo se manifiesta, así, en la subjetivización de la mirada sobre la realidad, aunque, a diferencia del cine de vanguardia, ahora no implica un rechazo absoluto de la narratividad: se cuenta una historia, pero a través de una forma enormemente personal, de un «estilo» mediante el que la subjetividad del autor actúa como filtro de la realidad narrada. Esa línea iniciada por los grandes cineastas del momento (Antonioni, Resnais, Bresson, Fellini, Godard, Truffaut, Casavettes, etc.) ha sido continuada por otros directores hasta nuestros días (Lynch, Tarkovski, Von Trier, Won Kar-Wai, Erice, Mahmalbaf, Kiarostami), cuya mirada personal, vehiculada a través de un estilo propio, consigue unos niveles considerables de indagación en la realidad y, consiguientemente, una dimensión lírica, que distancian a sus filmes del adocenamiento y la previsibilidad de las producciones industriales.

Aquí resulta obligado citar de nuevo a Gilles Deleuze, cuyas explicaciones sobre la categoría de imagen-tiempo (que considera definitoria del cine moderno en oposición a la de imagen-movimiento, ligada al modo de representación clásico) se sustentan en gran parte con ejemplos de la filmografía de esos «directores-autores» de los años sesenta. Según Rancière, los precursores de esa imagen que Deleuze concibe "como elemento de un encadenamiento natural con otras imágenes en una lógica de conjunto análoga a la del encadenamiento intencional de percepciones y acciones",

11. Un amplio repertorio de estas especulaciones en torno al binomio cine-poesía puede encontrarse en los dos volúmenes de la revista Litoral dedicados respectivamente a "La poesía del cine" (n. $\left.{ }^{\circ} 235,2003\right)$ y a "El cine y los poetas" $\left(n .^{\circ} 236,2004\right)$, coordinados ambos por Javier Herrera. 
una imagen «doblemente marcada por su temporalidad autónoma y por el vacío que la separa de las demás", tiene dos claros precursores ya en la década de los cuarenta: Roberto Rossellini y Orson Welles. Al primero se refiere Rancière como el «inventor de un cine de lo imprevisto, que opone al relato clásico la discontinuidad y ambigüedad esenciales de lo real», un cine cuya esencia se identifica "con su capacidad "realista" de revelar el sentido oculto de los seres y las cosas sin quebrar su unidad", un cine "de situaciones ópticas y sonoras puras que ya no se transforman en acciones». A Orson Welles, por su parte, lo define como «inventor de la profundidad de campo, opuesto a la tradición del montaje narrativo", en cuyo cine "la imagen actual ya no encadena con otra imagen actual, sino con su propia imagen virtual». Cada imagen -añade- "se separa entonces del resto para abrirse a su propia infinidad. Y lo que ahora se propone como enlace es la ausencia de enlace; el intersticio entre imágenes es lo que gobierna, en lugar del encadenamiento sensoriomotor, un reencadenamiento a partir del vacío» (Rancière 2005, 130-131).

No obstante, conviene aclarar que este llamado "cine de autor» no está circunscrito a un periodo ni a una geografía concretos, ya que se pueden encontrar manifestaciones en la filmografía de otros muchos cineastas de diversas épocas y países (Fritz Lang, Murnau, Dreyer, Renoir, Jacques Tati, Ozu o Mizoguchi, entre otros). En sus filmes, como afirma David Bordwell, «el sistema estilístico del filme crea pautas diferentes a las demandas del sistema argumental», con lo que "el estilo puede organizarse y enfatizarse hasta un grado que lo convierte, al menos, en tan importante como las pautas del argumento" (Bordwell 1996, 275-290).

Por otra parte, la poeticidad en todo este cine narrativo es una cuestión de grado y los filmes adscribibles a esta categoría pueden poseerla en muy diversa medida. Si bien sus autores tienen en común la resistencia a supeditar por completo la representación fílmica a los imperativos de la narratividad y, como señala Carmen Peña, están «mucho menos interesados en contar que en revelarnos una visión interior de las cosas» y en sus filmes "los objetos, las figuras, los movimientos de cámara, la luz [...] adquieren una existencia propia» sin subordinarse a los imperativos de la narración convencional (Peña Ardid 1997, 19).

Conviene recordar aquí, para ir concluyendo, la advertencia que hacía Étienne Fuzellier sobre el peligro de incurrir en la facilidad, en lo superficial, que suele amenazar a la poesía cinematográfica, sustituyendo el arte auténtico por el bibelot. Y añadía:

Al igual que la que la autenticidad poética en literatura no se mide por la exactitud concreta de las imágenes ni incluso por su belleza intrínseca, sino por la relación profunda que guardan con el "mensaje del poeta», el 
JOSÉ ANTONIO PÉREZ BOWIE

ALGUNAS NOTAS MÁS EN TORNO A LA CATEGORÍA DE CINE POÉTICO

poeta del cine debe ser juzgado ante todo por la elección que hace de las imágenes -premeditadas o no- que presenta, por las razones de esa elección, por la sinceridad de esas razones. Una de ellas es, evidentemente, su significación, es la traducción que proporciona de la visión personal de las emociones del poeta. La otra, no menos importante, es su valor rítmico (Fuzellier 1964, 94).

Y podemos cerrar con otras reflexiones en la misma línea de René Clair, quien, en un texto escrito en los años veinte, advertía que «la pantalla no deja lugar para otra poesía que la creada por la imagen misma», una poesía "de reglas imperceptibles y desconocidas». Y equiparaba, "las puestas de sol con que muchos realizadores pretenden despertar un sentimiento poético» a "recursos del mismo orden que "los raudos corceles» o "la noche lúgubre» de la poesía anticuada». La poesía del cine, concluía, "nace del ritmo de las imágenes» y citaba como ejemplo "el lirismo de un Sjöstrom o de un Griffith» (Clair 2003,116).

\section{RECAPITULACIÓN}

Como señalaba al comienzo de estas páginas, mi punto de partida lo constituyen algunos trabajos míos precedentes en los que, entre otros objetivos, intentaba trazar el recorrido histórico de la categoría de cine poético (2008, 51-69), me interrogaba sobre la existencia de un equivalente cinematográfico de la novela lírica (2011) o trataba de establecer una tipología de las diversas manifestaciones de ese formato (2015). Ahora, retomando esos trabajos, he intentado establecer con una mayor precisión el concepto de poeticidad cinematográfica y deshacer, en la medida de lo posible, el confusionismo reinante en torno al mismo. Para ello he ampliado el número de fuentes teóricas consultadas, y he sintetizado y confrontado sus aportaciones más significativas en una exposición que tiene como eje articulador la noción de narratividad: si admitimos que el cine alcanzó a lo largo del siglo xx la condición indiscutible de arte de masas y que esa condición se debió a una capacidad de narrar ficciones muy superior en accesibilidad y sugestión a la de las demás artes con las que hubo de competir, el cine poético se caracterizaría, en principio, por su oposición radical a esa dependencia de los públicos mayoritarios y por la búsqueda de nuevas vías mediante las que el nuevo arte pudiera desarrollar con plena autonomía su potencial creativo.

Pero la posición del cine poético frente a la narratividad admite matizaciones y resulta posible distinguir entre el rechazo total (antinarratividad) y la aceptación, condicionada a la posibilidad de perfeccionar sus 
mecanismos como vía de profundización en la realidad a la que se acerca (narratividad mitigada).

En el primer caso tenemos filmes de un elevado grado de experimentalidad, de vocación minoritaria y ajenos por completo a los circuitos de producción y exhibición habituales; unos filmes que son resultado, en su mayoría, del trabajo de investigación sobre los propios materiales y lenguajes desempeñado por todas las artes en los «laboratorios" de las vanguardias a lo largo de la historia y en los cuales se han abierto caminos para la renovación. En el caso del cine, el adjetivo "poético" está plenamente acorde con sus raí-

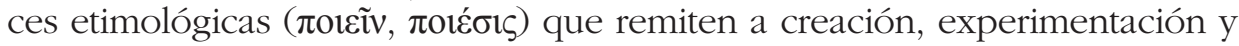
búsqueda, y puede ser aplicado a filmes como los mencionados, presididos por una vocación investigadora y renovadora impulsada por la insatisfacción ante la obsolescencia de los procedimientos habituales.

En el segundo caso, el adjetivo "poético» remite también a un propósito de creación, de búsqueda, aunque el cine al que se aplica esté integrado en el sistema de producción industrial y se consuma dentro de los circuitos de exhibición habituales, lo cual conlleva necesariamente la exigencia de contar historias. No obstante, la relevancia que adquieren los factores formales (el cómo se cuenta) puede atraer hacia estos la atención del espectador, la cual deja de estar supeditada exclusivamente al contenido (lo contado). La poeticidad se manifiesta, así, en una "escritura" propia, en un estilo que responde a la subjetividad del creador, a su personal visión de la realidad; una escritura que, como sucede en la poesía, se vuelve en ocasiones autoconsciente, por lo que la reflexividad es una de las características comunes a este cine. Todo ello lo aleja de la autorreferencialidad, indudablemente empobrecedora, común a los filmes antinarrativos, pues la relevancia de los factores formales no implica un empobrecimiento de los contenidos, sino lo contrario: como nos enseñaron los formalistas rusos, es la función extrañante de la forma artística la que desautomatiza nuestra percepción de la realidad y nos permite descubrir aspectos inéditos de la misma. Thierry Groensteen recordaba acertadamente que, en todo arte, forzar las posibilidades del propio lenguaje es, precisamente un paso progresivo que implica un acto de fe al asimilar la creación a una conquista del espíritu: aquello que una forma artística no parece ser capaz de expresar es precisamente lo que hay que intentar hacerle decir (Groensteen 1998, 28-29). No obstante, como advierten algunos de los teóricos citados, puede suceder que el despliegue de elementos formales no sea más que un ejercicio gratuito destinado a ocultar la ausencia de propuestas originales, en cuyo caso habría que hablar de cine seudopoético.

Tanto en la categoría de cine poético antinarrativo como en la de cine poético de narratividad mitigada nos encontramos con una gran variedad 
JOSÉ ANTONIO PÉREZ BOWIE

ALGUNAS NOTAS MÁS EN TORNO A LA CATEGORÍA DE CINE POÉTICO

de manifestaciones que a menudo coinciden con otras modalidades (cine experimental, ensayístico, autobiográfico, de autor, autoconsciente, autorreferencial, etc.), lo que se traduce en una confusión terminológica notable. Mi propósito no ha sido tanto trazar límites entre todas ellas, sino establecer dos líneas perfectamente diferenciadas a partir de las cuales resulte posible iniciar una sistematización de estas manifestaciones fílmicas.

Quedarían por abordar, además, otras varias cuestiones vinculadas a las relaciones entre cine y poesía a las que se alude en las páginas introductorias a este volumen; entre ellas, especialmente, el acercamiento a la poesía cinematográfica desde un enfoque pragmático, que tan rentable y esclarecedor está resultando en su aplicación a los textos literarios.

\section{REFERENCIAS BIBLIOGRÁFICAS}

AlBèra, François (comp.). 1998. Los formalistas rusos y el cine. La poética del filme. Barcelona: Paidós.

ARHEIM, Rudolf. 1996. El cine como arte. Barcelona: Paidós.

BORDWELl, David. 1996. La narración en el cine de ficción. Barcelona. Paidós.

BORDWELl, David y Kristine THOMPSON. 1995. El arte cinematográfico. Barcelona, Paidós.

Buñuel, Luis. 1970. «La dama de las camelias». En Aranda, J.F. Luis Buñuel. Biografía crítica. Barcelona: Lumen, pp. 309-310.

CASETTI, Francesco. 1994. Teorías del cine (1945-1990). Madrid: Cátedra.

Català, Josep M. ${ }^{a}$. 2005. «Film-ensayo y vanguardia». En TORReiro, C. y J. CERDÁn (eds.). Documental y vanguardia. Madrid: Cátedra, pp. 109-158.

ClaIR, René. 2003. "Cine puro y poesía». En Reflexiones. Notas para la historia del arte cinematográfico. 1920-1950. Litoral 235, pp. 114-118).

Deleuze, Gilles. 1984. La imagen-movimiento. Barcelona: Paidós.

Deleuze, Gilles. 1987. La imagen-tiempo. Barcelona: Paidós.

EikHenbaum, Boris. 1998a. «Problemas de cine-estilística». En Albèra, F. (comp.), pp. $45-75$.

EirhenBAUM, Boris. 1998b. «Literatura y cine». En AlBèra, F. (comp.), pp. 197-202.

EPSTEIN, Jean. 2003. «Cine-análisis o poesía en cantidad industrial». Litoral, 235, pp. 50-55.

ERICE, Víctor. 1997. "Cine poético». Poesía en el Campus, 36, pp. 3-4.

Fuzellier, Étienne. 1964. Cinéma et littérature. Paris: Les Éditions du Cerf.

Groensteen, Thierry. 1998. “Fictions sans frontières». En Gaudreault, A. y T. Groensteen (eds.). La transécriture. Colloque de Cerisy. Québec, Angoulême: Éditions Nota Bene, Centre National de la Bande Desinée et de l'Image, pp. 9-29.

HerRerA, Javier. 2004. «Poesía y poéticas en el cine moderno». Litoral, 236, pp. 6-17. KaZANSKI, Boris. 1998. «La naturaleza del cine». En Albèra, F. (comp.), pp. 101-134. 
Muñoz Fernández, Horacio. 2017. Posnarrativo. El cine más allá de la narración. Santander: Shangrila.

NeIra PiÑEIro, M. ${ }^{a}$ Rosario. 2007. "El lenguaje poético del cine. Procedimientos de simbolización en Un día de campo". Archivum LVI, pp. 291-311.

Oliva Mompeán, Ignacio. 1991. La imagen sustantiva. Elementos para una lógica de la forma moderna y su incidencia en el cine de los años veinte. Cuenca: Ediciones de la Universidad de Castilla-La Mancha.

Pasolini, Pier Paolo. 1970. "Cine de poesía». En Jordà, J. (ed.). Pier Paolo Pasolini contra Eric Rohmer. Cine de poesía contra cine de prosa. Barcelona: Anagrama, pp. 9-41.

PEÑA ARDID, Carmen. 1992. Literatura y cine. Una aproximación comparativa. Madrid: Cátedra.

PEÑa ARDID, Carmen. (1997). "El interrogante poético del cine». Poesía en el Campus, 36, pp. 13-19.

PÉREZ BowIE, José Antonio. 2008. Leer el cine. La teoría literaria en la teoría cinematográfica. Salamanca: Ediciones Universidad de Salamanca.

Pérez Bowie, José Antonio. 2011. "Notas sobre cine lírico. Un intento de tipología», disponible en http://congresoespanyola.fahce.unlp.edu.ar/ii-congreso-2011/ actas-ii-2011/volumen iii/III01PerezBowie.pdf

PÉREz BowIE, José Antonio. 2015. «Existe un equivalente cinematográfico de la novela lírica? Notas sobre la "narración mitigada" en la pantalla". ALEC, 40.1, pp. 281-309.

QuintanA, Ángel. 2011. Después del cine. Imagen y realidad en la era digital. Barcelona: Acantilado.

RANCIÈRE, Jacques. 2005. La fábula cinematográfica. Reflexiones sobre la ficción en el cine. Barcelona: Paidós,

ROHMER Eric. 1970. "Lo viejo y lo nuevo». En Jordà, J. (ed.). Pier Paolo Pasolini contra Eric Rohmer. Cine de poesía contra cine de prosa. Barcelona: Anagrama, pp. 42-80.

Romaguera, Joaquim y Homero Alsina. 1989. Textos y manifiestos del cine. Madrid: Cátedra.

SHKLOVSKI, Viktor. 1998. "Poesía y prosa en el cine». En Albèra, F. (comp.), pp. 135-138.

Sitney, P. Adams. 1979. Visionary Film. The American Avant-Garde 1934-1978. Oxford: Oxford University Press.

TARKOvSKI, Andrei. 2005. Esculpir en el tiempo. Madrid: Rialp.

TORRE, Guillermo de. 1926. "Cinema». Revista de Occidente, XII, pp. 116-120.

TORRE, Guillermo de. 1986. «El cinema y la novísima literatura: sus conexiones». En RozAs, J.M. (ed.). La generación del 27 desde dentro. Madrid: Ediciones Alcalá, pp. $156-160$.

Tynianov, Yuri. 1998. «Los fundamentos del cine». En AlBÈra, F. (comp.), pp. 77-100. VAllet, Antoine. 1963. Les genres du cinéma. Paris: Ligel. 
